\title{
Arsenate causes differential acute toxicity to two P-deprived genotypes of rice seedlings (Oryza sativa L.)
}

\author{
C.N. Geng ${ }^{1,2}$, Y.G. Zhu ${ }^{1,4}$, Y. Hu ${ }^{1}$, P. Williams ${ }^{3}$ \& A.A. Meharg ${ }^{3}$ \\ ${ }^{1}$ Research Center for Eco-environmental Sciences, Chinese Academy of Sciences, 100085 Beijing, China. \\ ${ }^{2}$ Shanghai Academy of Environmental Sciences, 200233 Shanghai, China. ${ }^{3}$ School of Biological Sciences, \\ University of Aberdeen, Cruickshank Building, St. Machar Drive, AB25 2TE Aberdeen, UK. ${ }^{4}$ Corresponding \\ author*
}

Received 5 May 2005. Accepted in revised form 6 August 2005

Key words: acute toxicity, antioxidants, arsenic, rice, stress level

\begin{abstract}
Significant genotypic difference in response to arsenate toxicity in rice (Oryza sativa) was investigated in root elongation, arsenate uptake kinetics, physiological and biochemical response and arsenic (As) speciation. Uptake kinetics data showed that P-deprived genotype 94D-54 had a little higher As uptake than P-deprived 94D-64, but the difference was not large enough to cause acute toxicity in P-deprived 94D54. There was no difference in tissue $\mathrm{P}$ concentrations between the two genotypes under $\mathrm{P}$ deficient conditions. In addition, arsenic speciation in plant tissues (using high performance liquid chromatographyinductively coupled plasma mass spectrometry) was not different between $\mathrm{P}$ pretreatments and between genotypes. P-deprived genotype 94D-54 suffered much higher stress induced by arsenate toxicity than P-deprived genotype 94D-64, in terms of lipid peroxidation, tissue $\mathrm{H}_{2} \mathrm{O}_{2}$ concentrations and exosmosis of K, P and As. However, P-deprived 94D-54 also had higher overproduction of enzymatic antioxidants (with higher GPX, SOD, CAT) and NPT (non-protein thiols) than P-deprived 94D-64. It appeared that, the higher sensitivity of P-deprived 94D-54 to arsenate toxicity might cause the overproduction of NPT, thus leading to the depletion of GSH and to the accumulation of $\mathrm{H}_{2} \mathrm{O}_{2}$. The differential sensitivity of the two genotypes has major implications for breeding rice for As affected paddy soil.
\end{abstract}

\section{Introduction}

Arsenate (dominant in aerobic conditions) acts as a phosphate analogue and is transported across the plasma membrane via phosphate transport systems (Dixon, 1997). Once inside the cytoplasm it competes with phosphate, for example replacing phosphate in ATP to form unstable ADParsenate and leading to the disruption of energy flows in cells (Hartley-Whitaker et al., 2001; Meharg and Hartley-Whitaker, 2002). However, arsenate will not normally have high enough cytoplasmic concentrations to exert toxicity because arsenate is rapidly reduced to arsenite in

\footnotetext{
* Fax No. + 86-10-62923563.

E-mail: ygzhu@mail.rcees.ac.cn
}

plant tissues (Bertolero et al., 1987). Arsenite is more toxic to plants than arsenate as it reacts with sulfhydryl groups (-SH) of enzymes and tissue proteins, leading to the inhibition of cellular function and even cell death (Delnomdedieu et al., 1993; Ullrich-Eberius et al., 1989). For example, arsenic (As) toxicity in rice seedlings causes perturbations in carbohydrate metabolism, leading to the accumulation of soluble sugars by altering enzyme activity (Jha and Dubey, 2004). Furthermore, arsenic compounds generate reactive oxygen species (ROS) during their metabolism in cells to cause tissue damages (Liu et al., 2001), which causes lipid peroxidation (HartleyWhitaker et al., 2001).

Plants also have evolved some mechanisms to detoxify As toxicity. Enzymatic and 
non-enzymatic antioxidants are induced to quench ROS (Hartley-Whitaker et al., 2001). It has been demonstrated that catalase (CAT), glutathione-S-transferase (GST) and superoxide dismutase (SOD) in Zea mays were all stimulated upon exposure to arsenate and arsenite (Mylona et al., 1998). Phytochelatins (PCs), thiol (SH)-rich peptides, forms As-SH complexes to detoxify As toxicity (Jocelyn, 1972; Scott et al., 1993). The production of PCs in response to inorganic As has been demonstrated in a number of plant species (Hartley-Whitaker et al., 2001; Raab et al., 2004; Schmöger et al., 2000; Sneller et al., 1999). It has been demonstrated that As-SH complexes can be transported into the vacuole by ycflp and confers arsenite resistance in yeast (Ghosh et al., 1999), and it has been suggested that higher plants may have similar mechanism in arsenite resistance (Tong et al., 2004).

In addition to the detoxification pathway through antioxidants and PCs, it has been hypothesized that there are two pathways in which phosphate is involved in As resistant mechanisms in higher plants. One is through reducing As uptake due to the suppression of the high-affinity phosphate/arsenate uptake system (Meharg and Macnair, 1992), and the other is through the over-accumulation of shoot $\mathrm{P}$, such as in the case of Arabidopsis ars1 mutant (Lee et al., 2003). When screening As resistance in rice, we found two rice (Oryza sativa) genotypes (94D-54 \& 94D-64) with significantly different resistance to As toxicity, but the difference in uptake and metabolism was not so large to interpret the significantly different resistance. Thus, a series of experiments were carried out to investigate the difference in physiological and biochemical changes and in As speciation in the two rice genotypes under As toxicity in solution culture.

\section{Materials and method}

\section{Preparation of rice seedlings}

Three types of nutrient solution were used in the present work, including no $\mathrm{P}(-\mathrm{P})$, plus $\mathrm{P}(+\mathrm{P})$ and no $\mathrm{P}$ plus As $(-\mathrm{P}+\mathrm{As})$. Plus $\mathrm{P}$ solution was the same as that of Liu et al. (2004). No P solution was made from $+\mathrm{P}$ solution by replacing
$\mathrm{KH}_{2} \mathrm{PO}_{4}$ with the same molar concentration of $\mathrm{KCl}$. The $-\mathrm{P}+\mathrm{As}$ solution was made by adding $26.7 \mu M \mathrm{Na}_{3} \mathrm{AsO}_{4} \cdot 12 \mathrm{H}_{2} \mathrm{O}$ into the $-\mathrm{P}$ solution.

Seeds of two genotypes (94D-54, 94D-64) of rice were surface sterilized in $10 \% \quad \mathrm{H}_{2} \mathrm{O}_{2}(\mathrm{v} / \mathrm{v})$ solution for $15 \mathrm{~min}$, followed by thorough washing with de-ionized water. The seeds were germinated for $25 \mathrm{~d}$ in moist perlite in a plastic pot (size 1.5 L). During the seed germination period, $50 \mathrm{~mL}+\mathrm{P}$ solution was supplied twice a week.

All nutrient solutions were changed twice per week, and $\mathrm{pH}$ was adjusted to 5.5 using $0.1 \mathrm{M}$ $\mathrm{KOH}$ or $\mathrm{HCl}$. The nutrient solution was not aerated during the experimental period to mimic the anaerobic conditions in paddy soils. Each treatment had three replicates. The experiment was carried out in a growth chamber with a $14 \mathrm{~h}$ light period $\left(260-350 \mu \mathrm{mol} \mathrm{m} \mathrm{m}^{-2} \mathrm{~s}^{-1}\right)$, relative humidity $70 \%$ and temperatures of $28^{\circ} \mathrm{C}$ at day and $20{ }^{\circ} \mathrm{C}$ at night. Pots were arranged randomly in the growth chamber and re-arranged every day.

\section{Experiment 1: Arsenate toxicity test-root elongation}

Rice seedlings of the two genotypes were raised as described above. Seedlings were allowed to grow in $+\mathrm{P}$ solution for $10 \mathrm{~d}$. After the pre-culture, uniform seedlings were then transferred to $500 \mathrm{~mL}$ PVC pots filled with either phosphate free nutrient

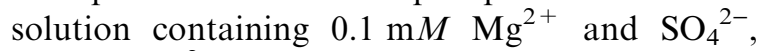
$0.2 \mathrm{mM} \mathrm{Ca}^{2+}$ and $\mathrm{K}^{+}$and $0.6 \mathrm{mM} \mathrm{NO}_{3}^{-}$(control), or the same nutrient solution supplemented with arsenate (as $\mathrm{Na}_{3} \mathrm{AsO}_{4} \cdot 12 \mathrm{H}_{2} \mathrm{O}$ ) at the concentrations of $5,10,20,40,80$ and $120 \mu \mathrm{M}$. Growth conditions are the same as described above. After one week, the maximum root length was measured.

Pretreatment of rice seedlings with or without $P$ (for Experiment 2-4)

Rice seedlings of the two genotypes were raised as described above. Seedlings were allowed to grow in $+\mathrm{P}$ solution for $20 \mathrm{~d}$. Then the seedlings were rinsed three times with de-ionized water. Then half of the seedlings were transferred to $-\mathrm{P}$ solution and the remaining seedlings were transferred to $+\mathrm{P}$ solution. All seedlings were pretreated by $-\mathrm{P}$ or $+\mathrm{P}$ solution for another $9 \mathrm{~d}$. 


\section{Experiment 2: Arsenic accumulation}

After $\mathrm{P}$ pretreatments, rice seedlings were exposed to $-\mathrm{P}+$ As solution for $48 \mathrm{~h}$. The seedlings were then harvested, oven dried and weighed. $\mathrm{P}$ and As concentrations in roots and shoots were analyzed according to Geng et al. (2005).

\section{Experiment 3: Arsenic uptake kinetics}

After $\mathrm{P}$ pretreatments, rice seedlings were exposed to $-\mathrm{P}+\mathrm{As}$ solution for $20.7 \mathrm{~h}$. At time intervals up to $20.7 \mathrm{~h}, 1 \mathrm{~mL}$ solution was sampled for As analysis by an AF-610A atomic fluorescence spectrometry (Beijing Ruili Analytical Instrument Co., Beijing, China). Water losses through transpiration were compensated by the addition of de-ionized water at hourly intervals according to Zhao et al. (2002).

\section{Experiment 4: Physiological and biochemical changes under arsenic stress}

After P pretreatments, rice seedlings (94D-54 \& 94D-64) were exposed to $-\mathrm{P}+\mathrm{As}$ solution for $4 \mathrm{~h}$. Fresh plant materials were sampled to measure physiological and biochemical indices. Activities of antioxidant enzymes such as guaiacol peroxidase (GPX, E.C. 1.11.1.7), SOD (E.C. 1.15.1.1) and CAT (E.C. 1.11.1.6) were measured according to Aravind and Prasad (2003) and Mazhoudi et al. (1997). Non-protein-thiols (NPT) were measured according to Sharma et al. (2004). $\mathrm{H}_{2} \mathrm{O}_{2}$ was measured according to Mulherjee and Choudhuri (1983). Freeze-dried plant materials were used for As speciation analysis (see below) according to Quaghebeur and Rengel (2003). The exosmosis of K, P and As was measured according to Llamas et al. (2000) and after measurement of ionic exomosis, freeze-dried root materials were used to measure the production of lipid peroxidation, malondialdehyde (MDA) according to Aravind and Prasad (2003).

\section{Arsenic speciation analysis of plant materials}

Freeze-dried plant materials (from Experiment 4, $0.05 \mathrm{~g}$ of root and $0.1 \mathrm{~g}$ of shoot) were digested in $3 \mathrm{~mL}$ of methanol: de-ionized water. Digests were heated on a digestion block at $100{ }^{\circ} \mathrm{C}$ for two hours and then boiled dry at $140{ }^{\circ} \mathrm{C}$. The residue was then re-suspended in $1 \%$ nitric acid to a mass of $10 \mathrm{~g}$.

As speciation in nitric acid was detected according to Quaghebeur et al. (2003) and Quaghebeur and Rengel (2003). Chromatographic columns were obtained from Hamilton and consisted of a precolumn $(11.2 \mathrm{~mm}, 12-20 \mu \mathrm{m})$ and a PRP-X100 anion-exchange column (150x $4.1 \mathrm{~mm}$ ). AHP1100 HPLC system (Agilent Technologies, Stockport, Cheshire, UK) with cooled auto-sampler and a Peltier controlled column compartment was used for all of the analysis. The auto-sampler was set to $4{ }^{\circ} \mathrm{C}$ and the column to $30^{\circ} \mathrm{C}$. Injection volume was set at either 10 or $100 \mu \mathrm{L}$ of sample and the mobile phase was maintained at $1 \mathrm{~mL} \mathrm{~min}{ }^{-1}$. The mobile phase employed for anion-exchange chromatography, adapted from Heitkemper et al. (2001), consisted of $6.66 \mathrm{mM}$ ammonium hydrophosphate $\left(\mathrm{NH}_{4} \mathrm{H}_{2} \mathrm{PO}_{4}\right)$ and $6.66 \mathrm{mM}$ ammonium nitrate $\left(\mathrm{NH}_{4} \mathrm{NO}_{3}\right), \mathrm{pH}$ 6.2. Each analysis was performed within three days of sample extraction, to minimize any changes in species due to prolonged storage.

Post-column, element specific detection of arsenic was achieved using an ICP-MS 7500 (Agilent Technologies). Arsenic sensitivity was monitored daily and optimized when required. The outlet of the HPLC was connected, via PTFE tubing to a T-piece. Internal standard was pumped using the ICP-MS's peristaltic pump and mixed with the column effluent in the T-piece, which connected directly to the inlet of the ICPMS neubulizer. Signals at $m / z 75,77$ and 115 were measured. Chromatographic peaks were integrated using WinFAAS software (Institute for Analytical Chemistry, Austria) and their concentration determined using a five-point calibration curve of $\mathrm{DMA}^{(\mathrm{V})}(0,1,25,50$, and $100 \mu \mathrm{g}$ of $\mathrm{As} \mathrm{L}^{-1}$ ).

\section{Results}

Arsenate toxicity test-root elongation

In the absence of arsenate in the growth solution, genotype 94D-54 had much longer root that genotype 94D-64 (Figure 1). With increasing arsenate concentrations in the growth solution, 
genotype 94D-54 had more drastic reduction in maximum root length than genotype 94D-64. Arsenate concentration at $5 \mu M$ resulted in a $50 \%$ reduction in maximum root length of genotype 94D-54, while genotype 94D-64 had little reduction in maximum root length with increasing arsenate concentrations in the growth solution at 40 and $120 \mu M$ arsenate.

\section{Plant growth, tissue $P$ and As concentrations}

P-deprived plants had lower biomass than P-sufficient plants (Table 1). Genotype 94D-64 had lower shoot biomass than genotype 94D-54 at both $\mathrm{P}$ treatments. For both genotypes, P-deprived plants had much lower tissue $\mathrm{P}$ concentrations than P-sufficient plants. Exposure to As just for $4 \mathrm{~h}$, P-deprived genotype 94D-54 showed acute toxic symptoms with leaves curled, and died after exposure to As for $48 \mathrm{~h}$. However, genotype 94D-64 showed no toxic symptoms. There was no significant difference in root As concentrations between $\mathrm{P}$ pretreatments, and shoot As concentrations were slightly but significantly higher in P-sufficient plants than in P-deprived ones. There was no significant difference in shoot As concentrations between the genotypes, and root As concentrations in genotype 94D-64 were higher than in genotype 94D-54.

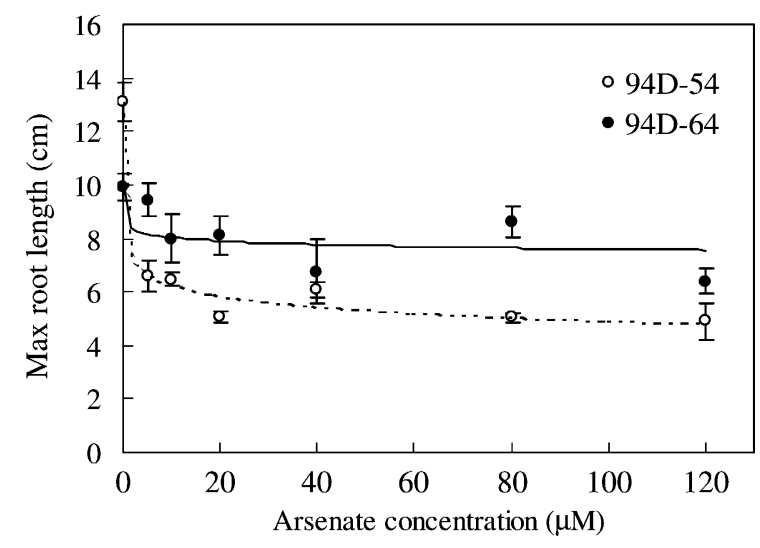

Figure 1. Root elongation in response to arsenate in two rice genotypes (94D-54 \& 94D-64). The seedlings were first precultured in $+\mathrm{P}$ solution for 10 days and then were transferred into nutrient solution supplemented with arsenate (as $\mathrm{Na}_{3} \mathrm{AsO}_{4} \cdot 12 \mathrm{H}_{2} \mathrm{O}$ ) at the concentrations of $0,5,10,20$, 40, 80 and $120 \mu M$ for seven days and finally were measured the maximum root length. The error bars represent one SE of the mean from four replicates.
Table 1. Biomass and tissue $\mathrm{P}$ and As concentrations in two rice (O. sativa) genotypes (94D-54 and 94D-64). The seedlings were first pre-cultured with $+\mathrm{P}$ solution for $20 \mathrm{~d}$, and then pretreated with $-\mathrm{P}$ and $+\mathrm{P}$ solution for $9 \mathrm{~d}$ and finally exposed to $-\mathrm{P}+\mathrm{As}$ solution $\left(26.7 \mu M \mathrm{Na}_{3} \mathrm{AsO}_{4} \cdot 12 \mathrm{H}_{2} \mathrm{O}\right)$ for $2 \mathrm{~d}$. Values are the mean $\pm \mathrm{SE}(n=3)$

\begin{tabular}{|c|c|c|c|c|c|}
\hline \multirow[t]{3}{*}{$\mathrm{P}$ pretreatment } & & \multicolumn{4}{|l|}{ Genotypes } \\
\hline & & \multicolumn{2}{|l|}{ 94D-54 } & \multicolumn{2}{|c|}{ 94D-64 } \\
\hline & & $-\mathrm{P}$ & $+\mathrm{P}$ & $-\mathrm{P}$ & $+\mathrm{P}$ \\
\hline \multirow[t]{2}{*}{ Biomass (g) } & Root & 0.23 & 0.25 & 0.19 & 0.22 \\
\hline & Shoot & 0.96 & 1.21 & 0.70 & 0.86 \\
\hline \multirow[t]{2}{*}{$\mathrm{P}(\mathrm{mg} / \mathrm{g})$} & Root & 2.2 & 6.6 & 2.3 & 7.3 \\
\hline & Shoot & 4.6 & 14.4 & 3.4 & 13.0 \\
\hline As $(\mathrm{mg} / \mathrm{g})$ & Root & 1.16 & 1.29 & 1.54 & 1.38 \\
\hline As $(\mathrm{mg} / \mathrm{kg})$ & Shoot & 26.0 & 31.5 & 26.5 & 35.6 \\
\hline \multicolumn{6}{|c|}{ Analysis of variance } \\
\hline & & $\begin{array}{l}\text { Genotypes } \\
\text { (G) }\end{array}$ & $\mathrm{P}$ & $\mathrm{G} \times \mathrm{P}$ & \\
\hline \multirow[t]{2}{*}{ Biomass } & Root & ns & 0.011 & ns & \\
\hline & Shoot & $<0.001$ & $<0.001$ & ns & \\
\hline \multirow[t]{2}{*}{$\mathrm{P}$} & Root & ns & $<0.001$ & ns & \\
\hline & Shoot & ns & $<0.001$ & ns & \\
\hline \multirow[t]{2}{*}{ As } & Root & $<0.001$ & ns & 0.034 & \\
\hline & Shoot & ns & 0.025 & Ns & \\
\hline
\end{tabular}

ns refers to not significant at the level 0.05 .

\section{Time-dependent As uptake}

For both genotypes, P-sufficient plants had lower As uptake than P-deprived plants. P-deprived 94D-54 had a little higher As uptake rate than Pdeprived 94D-64 (Figure 2). Exposure to $26.7 \mu M$ arsenate for $400 \mathrm{~min}$, both genotypes reached the highest As uptake. There were no differences in arsenic speciation between genotypes or between $\mathrm{P}$ pretreatment in this experiment. Similar to Experiment 2, P-deprived genotype 94D-54 showed acute toxic symptoms when exposure to As just for $4 \mathrm{~h}$. Thus, exposure time for experiment 4 was just $4 \mathrm{~h}$ to avoid plant death.

\section{Physiological and biochemical response to arsenate exposure}

In $-\mathrm{P}$ pretreatment, genotype $94 \mathrm{D}-54$ had higher MDA, $\mathrm{H}_{2} \mathrm{O}_{2}$ in roots and shoots than genotype 94D-64 (Table 2). Furthermore, genotype 94D-54 also had higher $\mathrm{K}, \mathrm{P}$ and As concentrations in exosmotic solution than genotype 94D-64 at both $\mathrm{P}$ pretreatments (Figure 3; Table 3). For both 


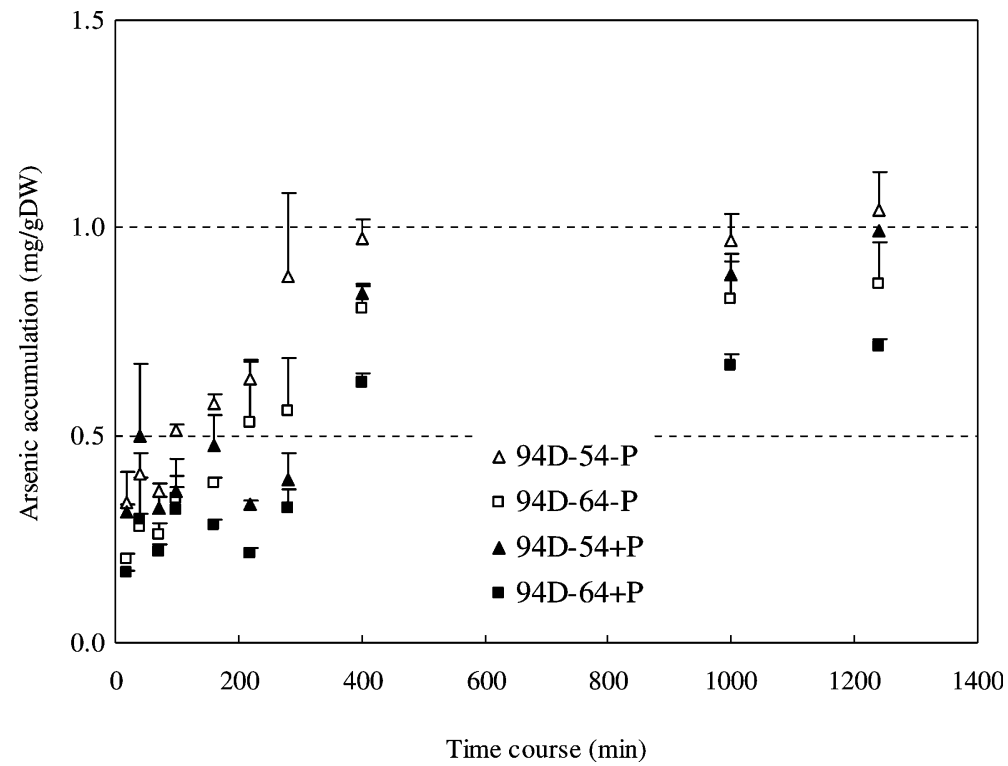

Figure 2. Accumulation of As by two rice genotypes (94D-54 \& 94D-64) in the uptake experiment (expressed on the basis of root dry weight). The seedlings were first pre-cultured with $+\mathrm{P}$ solution for $20 \mathrm{~d}$, and then pretreated with $-\mathrm{P}$ and $+\mathrm{P}$ solution for $9 \mathrm{~d}$ and finally exposed to $-\mathrm{P}+$ As solution $\left(26.7 \mu M \mathrm{Na}_{3} \mathrm{AsO}_{4} \cdot 12 \mathrm{H}_{2} \mathrm{O}\right)$ for $20.7 \mathrm{~h}$. Values are the means of three replicates.

genotypes, $\mathrm{P}$ pretreatment decreased $\mathrm{K}$ and As concentrations in exosmotic solution, but $\mathrm{P}$ pretreatment had no effect on $\mathrm{P}$ exosmosis.

For both genotypes, $\mathrm{P}$ supply significantly increased shoot but not root GPX (Figure 4; Table 3). Little genotypic difference in GPX

Table 2. MDA and $\mathrm{H}_{2} \mathrm{O}_{2}$ in two rice $O$. sativa genotypes (94D-54 \& 94D-64). The seedlings were first pre-cultured with $+\mathrm{P}$ solution for $20 \mathrm{~d}$, and then pretreated with $-\mathrm{P}$ and $+\mathrm{P}$ solution for $9 \mathrm{~d}$ and finally exposed to $-\mathrm{P}+\mathrm{As}$ solution $\left(26.7 \mu M \quad \mathrm{Na}_{3} \mathrm{AsO}_{4} \cdot 12 \mathrm{H}_{2} \mathrm{O}\right)$ for $4 \mathrm{~h}$. Values are the mean $\pm \operatorname{SE}(n=3)$

\begin{tabular}{|c|c|c|c|c|c|}
\hline & & \multicolumn{2}{|c|}{ 94D-54 } & \multicolumn{2}{|c|}{$94 \mathrm{D}-64$} \\
\hline & & $-\mathrm{P}$ & $+\mathrm{P}$ & $-\mathrm{P}$ & $+\mathrm{P}$ \\
\hline \multirow[t]{2}{*}{$\operatorname{MDA}(\mu \mathrm{mol} / \mathrm{kg} \mathrm{DW})$} & Root & 25.0 & 29.7 & 21.1 & 18.2 \\
\hline & Shoot & 20.0 & 20.4 & 11.6 & 11.4 \\
\hline \multirow[t]{2}{*}{$\mathrm{H}_{2} \mathrm{O}_{2}(\mu \mathrm{mol} / \mathrm{kg} \mathrm{FW})$} & Root & 1250 & 374 & 417 & 319 \\
\hline & Shoot & 1833 & 1307 & 1254 & 1290 \\
\hline \multicolumn{6}{|l|}{ Analysis of variance } \\
\hline & & \multicolumn{2}{|c|}{$\begin{array}{l}\text { Genotype } \\
\text { (G) }\end{array}$} & $P$ & $\mathrm{G} \times \mathrm{P}$ \\
\hline \multirow[t]{2}{*}{ MDA } & Root & \multicolumn{2}{|l|}{0.003} & $\mathrm{~ns}$ & ns \\
\hline & Shoot & \multicolumn{2}{|l|}{0.001} & ns & ns \\
\hline \multirow[t]{2}{*}{$\mathrm{H}_{2} \mathrm{O}_{2}$} & Root & \multicolumn{2}{|l|}{0.038} & 0.03 & 0.051 \\
\hline & Shoot & \multicolumn{2}{|l|}{ ns } & ns & ns \\
\hline
\end{tabular}

ns refers to not significantly at the level 0.05 . was found in shoots at both $\mathrm{P}$ pretreatments, but genotype 94D-54 had higher GPX than genotype $94 \mathrm{D}-64$ in roots under $-\mathrm{P}$ pretreatment. + $\mathrm{P}$ pretreatment only resulted in lower SOD in the shoots of genotype 94D-54. Genotype 94D-54 had higher shoot SOD than genotype 94D-64 under $-\mathrm{P}$ pretreatment. For both genotypes, $\mathrm{P}$ supply reduced CAT both in roots and shoots. At both $\mathrm{P}$ pretreatments, genotype 94D-54 had higher root CAT than genotype 94D-64. In -P pretreatment, genotype 94D-54 had much higher NPT in shoots than genotype 94D-64. For both genotypes, -P pretreatment significantly increased shoot NPT. NPT was under detection limit in shoots of genotype 94D-64 pretreated with $+\mathrm{P}$ solution and in roots of both genotypes at both $\mathrm{P}$ pretreatments.

\section{As speciation in plant tissues}

Under P-deprived conditions the percentage of As extracted in methanol: water was around $60 \%$, dramatically higher than that in P-sufficient conditions (20\%; Table 4). No methylated organic arsenic species were detected in the methanol: water extract, and the proportion of arsenite to arsenate remained constant in all treatments. 

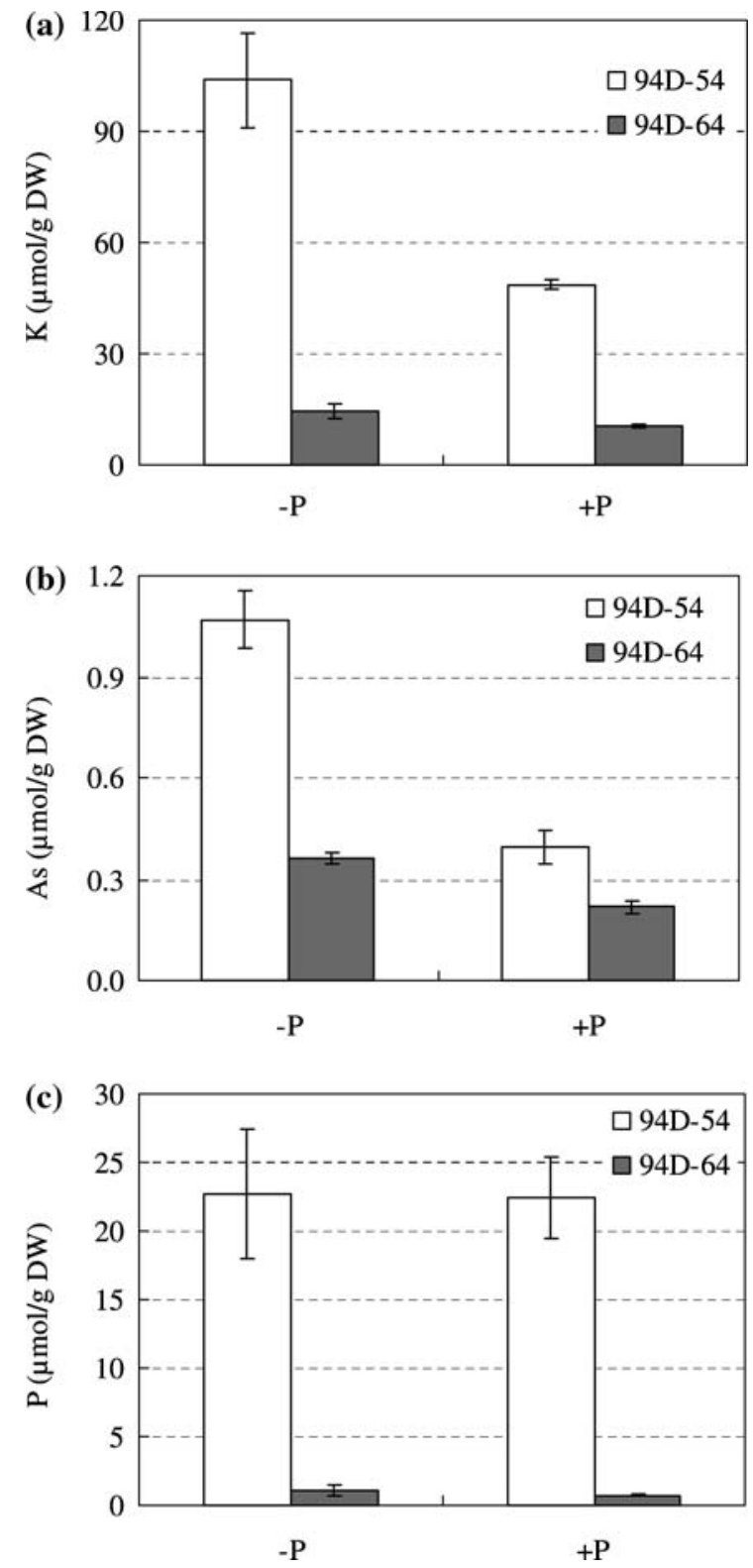

Figure 3. Exosmosis of K (a), As (b)\& P (c) by two rice genotypes (94D-54 \& 94D-64). The seedlings were first pretreated with $+\mathrm{P}$ solution for $20 \mathrm{~d}$, and then treated with $-\mathrm{P}$ and $+\mathrm{P}$ solution for $9 \mathrm{~d}$ and finally exposed to $-\mathrm{P}+\mathrm{As}$ solution $\left(26.7 \mu M \quad \mathrm{Na}_{3} \mathrm{AsO}_{4} \cdot 12 \mathrm{H}_{2} \mathrm{O}\right)$ for $4 \mathrm{~h}$. Values are the mean $\pm \operatorname{SE}(n=3)$.

\section{Discussion}

P-deprived 94D-54 showed acute toxicity to arsenate. Toxicity test also confirmed that genotype 94D-54 was more sensitive to arsenate than genotype 94D-64 (Figure 1). What caused the
Table 3. Analysis of variance (two-way ANOVA) on exosmosis of K, P \& As and GPX, SOD, CAT and NPT by two rice $O$. sativa genotypes (94D-54 \& 94D-64) shown in Figures 3 and 4

\begin{tabular}{llll}
\hline & Genotype $(\mathrm{G})$ & $\mathrm{P}$ & $\mathrm{G} \times \mathrm{P}$ \\
\hline $\mathrm{K}$ & $<0.001$ & 0.002 & 0.004 \\
$\mathrm{As}$ & $<0.001$ & $<0.001$ & 0.001 \\
$\mathrm{P}$ & $<0.001$ & $\mathrm{~ns}$ & $\mathrm{~ns}$ \\
Root GPX & 0.037 & $\mathrm{~ns}$ & $\mathrm{~ns}$ \\
Shoot GPX & $\mathrm{ns}$ & 0.021 & $\mathrm{~ns}$ \\
Root SOD & 0.02 & $\mathrm{~ns}$ & $\mathrm{~ns}$ \\
Shoot SOD & $\mathrm{ns}$ & 0.02 & 0.005 \\
Root CAT & 0.002 & 0.046 & $\mathrm{~ns}$ \\
Shoot CAT & $\mathrm{ns}$ & 0.011 & $\mathrm{~ns}$ \\
Shoot NPT & 0.001 & $<0.001$ & 0.002 \\
\hline
\end{tabular}

ns refers to not significantly at the level 0.05 .

acute toxicity of P-deprived 94D-54 to arsenate? The mechanism of As-tolerance in 94D-64 was different from "classic" As tolerance found in Arabidopsis arsl mutant and in $H$. lanatus. In ars1 mutant, As-tolerance is acquired through the over-accumulation of shoot $\mathrm{P}$ compare to wild type (Lee et al., 2003). In H. lanatus, As-tolerance is acquired through reducing As uptake due to the suppression of the high-affinity phosphate/arsenate uptake system (Meharg and Macnair, 1992). But in our case, there was no difference in tissue $\mathrm{P}$ concentrations between 94D-64 and 94D-54 under P deficient conditions (Table 1). Although P-deprived 94D-54 had higher As uptake than P-deprived 94D-64 (Figure 2), but the difference was not so huge to cause acute toxicity. In addition, arsenite is more toxic to plants than arsenate. If P-deprived 94D-54 had more arsenite in root and shoot than P-deprived 94D-64, it could be understood that why P-deprived 94D-54 showed acute toxicity to arsenate. However, there was little difference in As speciation in 94D-54 and 94D-64 under $\mathrm{P}$ deficient conditions (Table 4).

P-deprived 94D-54 suffered higher stress from arsenate exposure than P-deprived 94D-64. After exposure to arsenate, lipid peroxidation was higher in P-deprived 94D-54 than in P-deprived 94D64 (Table 2). Hartley-Whitaker et al. (2001) have also demonstrated that arsenate caused lipid peroxidation in arsenate-sensitive $H$. lanatus, but in arsenate-tolerant plants, little lipid peroxidation was observed. These two results indicate that 

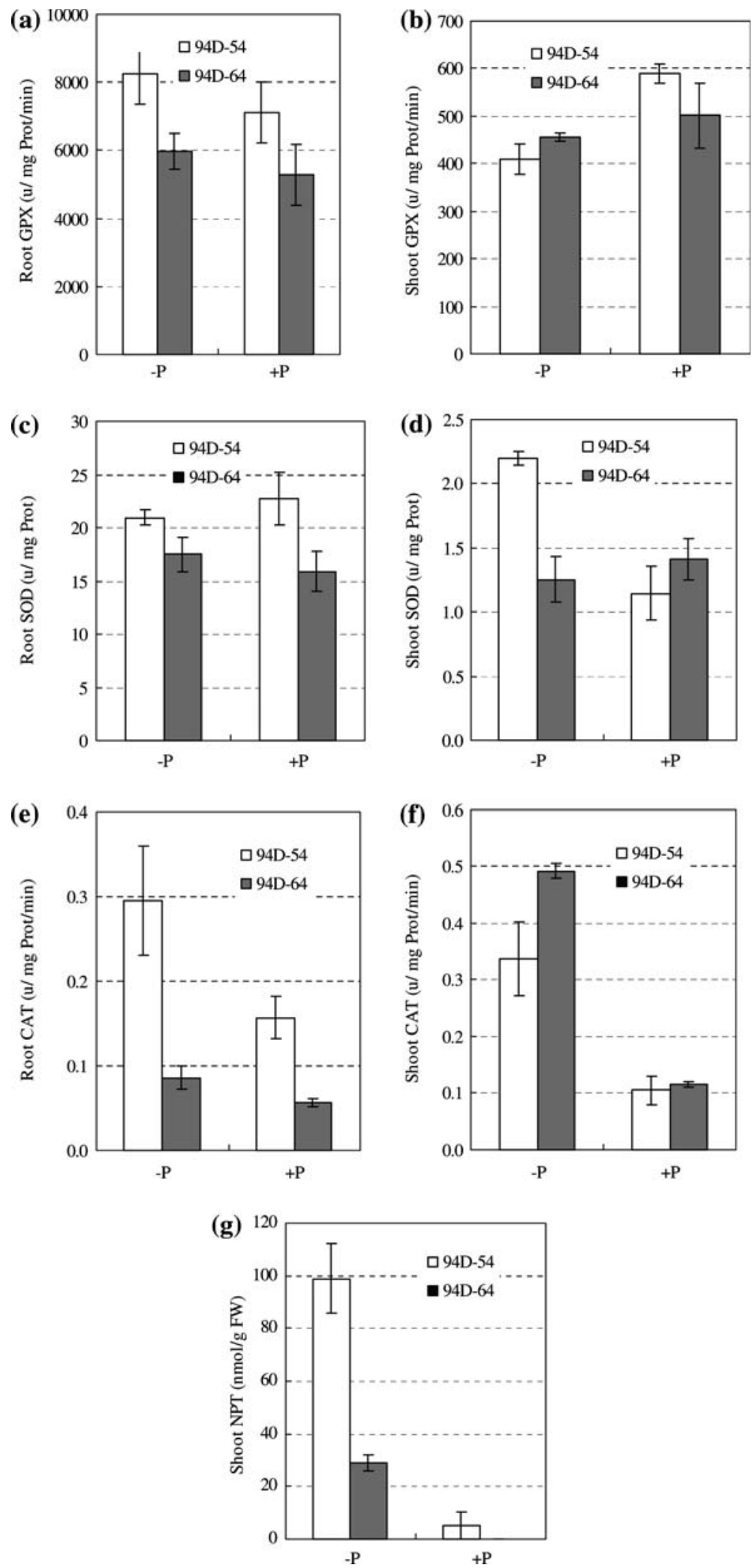
Figure 4. GPX (a, b), SOD (c, d), CAT (e, f) and NPT (g) in two rice genotypes (94D-54 \& 94D-64). The seedlings were first precultured with $+\mathrm{P}$ solution for $20 \mathrm{~d}$, and then pretreated with $-\mathrm{P}$ and $+\mathrm{P}$ solution for $9 \mathrm{~d}$ and finally exposed to $-\mathrm{P}+\mathrm{As}$ solution (26.7 $\left.\mu \mathrm{M} \mathrm{Na} \mathrm{Na}_{3} \mathrm{AsO}_{4} \cdot 12 \mathrm{H}_{2} \mathrm{O}\right)$ for $4 \mathrm{~h}$. Values are the mean $\pm \mathrm{SE}(n=3)$.

arsenate toxicity may result in the production of ROS, which in turn causes membrane damage. This hypothesis was confirmed by the fact that P-deprived 94D-54 also had higher $\mathrm{H}_{2} \mathrm{O}_{2}$ in roots and shoots than P-deprived 94D-64 (Table 2). Lipid peroxidation may result in structural destruction of cell membrane and further increase ionic exosmosis, which was confirmed by the fact that P-deprived 94D-54 also had higher exosmosis of K, P and As than P-deprived 94D-64 (Figure 3). In together, it was easily understood that higher stress in P-deprived 94D-54 made it more sensitive to arsenate exposure.

However, it was hard to understand that P-deprived 94D-54 also had higher non-enzymatic antioxidants and enzymatic antioxidants activities than P-deprived 94D-64. In plants, enzymatic and non-enzymatic antioxidants are induced to quench ROS produced by As. Nonenzymatic antioxidants include glutathione and ascorbate (Alscher, 1989; Dat et al., 2000), while enzymatic antioxidants include GPX, SOD, ascorbate peroxidase (APX) and CAT (Bowler et al., 1994; Gupta et al., 1999). P-deprived 94D54 had higher CAT and GPX in roots and SOD in shoots than P-deprived 94D-64 (Figure 4). In

Table 4. As speciation ( $\pm \mathrm{SD}, \mu \mathrm{g} / \mathrm{g}$ ) in shoots of the two rice genotypes (94D-54 and 94D-64). The seedlings were first precultured with $+\mathrm{P}$ solution for $20 \mathrm{~d}$, and then pretreated with $-\mathrm{P}$ and $+\mathrm{P}$ solution for $9 \mathrm{~d}$ and finally exposed to $-\mathrm{P}+\mathrm{As}$ solution $\left(26.7 \mu M \mathrm{Na}_{3} \mathrm{AsO}_{4} \cdot 12 \mathrm{H}_{2} \mathrm{O}\right)$ for $4 \mathrm{~h}$. Extraction efficiency referred to the percentage of arsenic recovered by methanol: water extraction as compared to total As in the plant for "Total As from sum of species"

\begin{tabular}{llllll}
\hline P pretreatment & $-\mathrm{P}$ & \multicolumn{3}{l}{$+\mathrm{P}$} \\
\cline { 2 - 3 } \cline { 5 - 6 } Genotypes & $94 \mathrm{D}-54$ & $94 \mathrm{D}-64$ & & $94 \mathrm{D}-54$ & $94 \mathrm{D}-64$ \\
\hline As (III) + As (V) & $16.9 \pm 6.6$ & $16.2 \pm 6.5$ & $5.0 \pm 2.7$ & $9.5 \pm 0.2$ \\
Extraction & & & & 16 & 27 \\
efficiency (\%) & 65 & 58 & & 16 & \\
As (III) & $8.9 \pm 4.0$ & $9.1 \pm 5.0$ & & $2.8 \pm 1.4$ & $5.6 \pm 0.0$ \\
Percentages (\%) & 53 & 56 & 56 & 59 \\
As (V) & $7.9 \pm 2.6$ & $6.0 \pm 2.6$ & & $2.2 \pm 1.4$ & $3.9 \pm 0.1$ \\
Percentages (\%) & 47 & 37 & 44 & 41 \\
\hline
\end{tabular}

P-deprived 94D-54 and 94D-64, high levels of lipid peroxidation corresponded with high levels of enzymatic antioxidant activities. However, in $H$. lanatus, high levels of lipid peroxidation negatively corresponded with the levels of SOD activity (Hartley-Whitaker et al., 2001). Overproduction of enzymatic antioxidants in P-deprived 94D-54 might be expected to correspond to the alleviation of As toxicity in this genotype, but this is not the case. Similar results have been found in Xanthomonas campestris, that the overproduction of peroxide-scavenging enzymes (KatA, AhpCF and Ohr) did not enhance As tolerance (Sukchawalit et al., 2004).

Phytochelatins (PCs) are thiol (SH)-rich peptides and induced by a range of heavy metals including $\mathrm{Cd}, \mathrm{As}, \mathrm{Cu}$, and $\mathrm{Zn}$ (Grill et al., 1985). The hypothesis that PCs was involved in the detoxification of arsenate was supported by the evidence of the formation of As-SH complexes both in vivo and in vitro (Jocelyn, 1972; Scott et al., 1993). Non-protein thiols (NPT) could indicate the levels of PCs (Metwally et al., 2005). In the present experiment, P-deprived 94D-54 had much higher NPT in shoots than P-deprived 94D-64 (Figure 4). Higher levels of NPT in P-deprived 94D-54 might be expected to correspond to the alleviation of As toxicity in this genotype. However, this is not the case, with genotype 94D-54 more sensitive to As toxicity. It is suggested that phytochelatin production may also lead to GSH depletion and produce oxidative stress because GSH is an important non-enzymatic agent to quench ROS (Hartley-Whitaker et al., 2001), which might partly explain the occurrence of high level of $\mathrm{H}_{2} \mathrm{O}_{2}$ in the sensitive genotype 94D-54 (Table 2).

In summary compared to P-deprived 94D-64, P-deprived 94D-54 appeared to possess a higher detoxification ability, but suffered higher stress level (Table 3; Figures 3 and 4). These results indicated that the high sensitivity of P-deprived 94D-54 to arsenate toxicity might be derived from the overproduction of NPT, which in turn cause the depletion of GSH, thus leading to the accumulation of $\mathrm{H}_{2} \mathrm{O}_{2}$ and lipid peroxidation. 


\section{Acknowledgements}

The work was financially supported by the Natural Science Foundation of China (40225002), the Ministry of Science and Technology of China (2002CB410808) and the Chinese Academy of Sciences (Hundred Talent Program). We thank Professor DM Li (Institute of Subtropical Regional Agriculture, Chinese Academy of Sciences) for supplying rice seeds.

\section{References}

Alscher R G 1989 Biosynthesis and antioxidant function of glutathione in plants. Physiol. Plantarum 77, 457-464.

Aravind P and Prasad M N V 2003 Zinc alleviates cadmiuminduced oxidative stress in Ceratophyllum demersum L: a free floating freshwater macrophyte. Plant Physiol. Bioch. 41, 391-397.

Bertolero F, Pozzi G, Sabbioni E and Saffiotti U 1987 Cellular uptake and metabolic reduction of pentavalent to trivalent arsenic as determinants of cytotoxicity and morphological transformation. Carcinogenesis 8, 803-808.

Bowler C, Van C W, Van M M and Inze D 1994 Superoxide dismutase in plants. Crit. Rev. Plant Sci. 13, 199-218.

Dat J, Vandenabeele S, Vranova E, Van M M, Inze D and Van B F 2000 Dual action of the active oxygen species during plant stress responses. Cell. Mol. Life Sci. 57, 779-795.

Delnomdedieu M, Basti M M, Otvos J D and Thomas D J 1993 Transfer of arsenite from glutathione to dithiols: A model of interaction. Chem. Res. Tox. 6, 598-602.

Dixon H B F 1997 The biochemical action of arsenic acids especially as phosphate analogues. Adv. Inorg. Chem. 44, 191-227.

Geng C N, Zhu Y G, Tong Y P and Christie P, 2005 Uptake and translocation of arsenic and phosphorus in pho2 mutant and wild type of Arabidopsis thaliana. J. Plant Nutr. (in press).

Ghosh M, Shen J and Rosen B P 1999 Pathways of As (III) detoxification in Saccharomyces cerevisiae. P. Natl. Acad. Sci. 96, 5001-5006.

Grill E, Winnacker E L and Zenk M H 1985 Phytochelatins: the principal heavy metal complexing peptides of higher plants. Science. 230, 674-676.

Gupta M, Cuypers A, Vangronsveld J and Clijsters H 1999 Copper affects the enzymes of the ascorbate-glutathione cycle and its related metabolites in the roots of Phaseolus vulgaris. Physiol. Plantarum 106, 262-267.

Hartley-Whitaker J, Ainsworth G and Meharg A A 2001 Copper- and arsenate-induced oxidative stress in Holcus lanatus L. clones with differential sensitivity. Plant Cell Environ. 24, 713-722.

Heitkemper D T, Vela N P, Stewart K R and Westphal C S 2001 Determination of totaland speciated arsenic in rice by ion chromatography and inductively coupled plasma mass spectrometry. J. Anal. Atom. Spectrom 16, 299-306.

Jha A B and Dubey R S 2004 Carbohydrate metabolism in growing rice seedlings under arsenic toxicity. J. Plant Physiol. 161, 867-872.
Jocelyn P C 1972 Biochemistry of the SH Group: The Occurrence, Chemical Properties, Metabolism and Biological Function of Thiols and Disulphides. Academic Press, London, UK.

Lee D A, Chen A and Schroeder J I 2003 Ars1, an Arabidopsis mutant exhibiting increased tolerance to arsenate and increased phosphate uptake. Plant J. 35, 637-646.

Liu S X, Athar M, Lippai I, Waldren C and Hei T K 2001 Induction of oxyradicals by arsenic: implication for mechanism of genotoxicity. P. Natl. Acad. Sci. USA. 98, 1643-1648.

Liu W J, Zhu Y G, Smith F A and Smith S E 2004 Do phosphorus nutrition and iron plaque alter arsenate (As) uptake by rice seedlings in hydroponic culture? New Phytol. $162,481-488$.

Llamas A, Uiirich C I and Sanz A $2000 \mathrm{Cd}^{2+}$ effects on transmembrane electrical potential difference, respiration and membrane permeability of rice (Oryza sativa $\mathrm{L}$ ) roots. Plant Soil. 219, 21-28.

Mazhoudi S, Chaoui A, Ghorbal M H and Ferjani E E 1997 Response of antioxidant enzymes to excess copper in tomato (Lycopersicon Esculentum Mill.). Plant Sci. 127, 129-137.

Meharg A A and Hartley-Whitaker J 2002 Arsenic uptake and metabolism in arsenic resistant and nonresistant plant species. New Phytol. 154, 29-43.

Meharg A A and Macnair M R 1992 Suppression of the highaffinity phosphate-uptake system - a mechanism of arsenate tolerance in Holcus Lanatus L. J. Exp. Bot. 43, 519-524.

Metwally A, Safronova V I, Belimov A A and Dietz K 2005 Genotypic variation of the response to cadmium toxicity in Pisum sativum L. J. Exp. Bot. 56, 167-178.

Mulherjee S P and Choudhuri M A 1983 Determination of glycolate oxidase activity, $\mathrm{H}_{2} \mathrm{O}_{2}$ content and catalase activity. Physiol. Plantarum 58, 167-170.

Mylona P V, Polidoros A N and Scandalios J G 1998 Modulation of antioxidant responses by arsenic in maize. Free Radical Bio. Med. 25, 576-585.

Quaghebeur M and Rengel Z 2003 The distribution of arsenate and arsenite in shoots and roots of holcus lanatus is influenced by arsenic tolerance and arsenate and phosphate supply. Plant Physiol. 132, 1600-1609.

Quaghebeur M, Rengel Z and Smirk M 2003 Arsenic speciation in terrestrial plant material using microwave-assisted extraction, ion chromatography and inductively coupled plasma mass spectrometry. J. Anal. At Spectrom 18, 128-134.

Raab A, Feldmann J and Meharg A A 2004 The Nature of Arsenic-Phytochelatin Complexes in Holcus lanatus and Pteris cretica. Plant Physiol. 134, 1113-1122.

Schmöger M E V, Oven M and Grill E 2000 Detoxification of arsenic by phytochelatins in plants. Plant Physiol. 122, 793 802.

Scott N, Hatlelid K M, MacKenzie N E and Carter D E 1993 Reactions of arsenic (III) and arsenic (V) species with glutathione. Chem. Res. Tox. 6, 102-106.

Sharma S S, Kaul S, Metwally A, Goyal K C, Finkemeier I and Karl-Josef D 2004 Cadmium toxicity to barley (Hordeum vulgare) as affected by varying $\mathrm{Fe}$ nutritional status. Plant Sci. 166, 1287-1295.

Sneller F E C, Van H L M, Kraaijeveld-Smit F J L, Ten B W M, Koevoets P L M, Schat H and Verkleij J A C 1999 Toxicity of arsenate in Silene vulgaris, accumulation and degradation of arsenate-induced phytochelatins. New Phytol. 144, 223-232.

Sukchawalit R, Prapagdee B, Charoenlap N, Vattanaviboon P and Mongkolsuk S 2005 Protection of Xanthomonas against 
arsenic toxicity involves the peroxide-sensing transcription regulator OxyR. Res. Microbiol. 156, 30-34.

Tong Y P, Kneer R and Zhu Y G 2004 Vacuolar compartmentalization: a second-generation approach to engineering plants for phytoremediation. Trends Plant Sci. 9, 7-9.

Ullrich-Eberius C, Sanz A and Novacky A J 1989 Evaluation of arsenate- and vanadate-associated changes of electrical membrane potential and phosphate transport in Lemna gibba G1. J. Exp.Bot. 40, 119-128.

Zhao F J, Dunham S J and McGrath S P 2002 Arsenic hyperaccumulation by different fern species. New Phytol. $156,27-31$

Section editor: A.J.M. Baker 